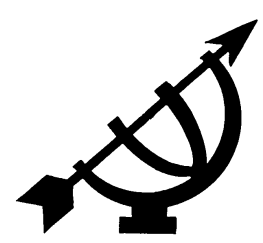

\title{
Integrasie of transformasie?
}

\section{"Geloof en wetenskap" of "gelowige wetenskap" as vertrekpunte vir integrale Christelike wetenskapsbeoefening}

\author{
B.J. van der Walt \\ Skool vir Filosofie \\ Potchefstroomkampus \\ Noordwes-Universiteit \\ POTCHEFSTROOM \\ E-pos: hannah@intekom.co.za
}

\begin{abstract}
Integration or transformation? "Faith and scholarship" or "faith-directed scholarship" as starting-point for integral Christain scientific endeavour
\end{abstract}

To be discussed in this article is the question whether the contemporary model of integration can be accepted as a valid way towards genuine Christian scholarship. To find an answer to this problem, the following steps are taken. In the introduction attention is asked for the present popularity - overseas as well as in South Africa - of this model of "faith and science". Subsequently, the meaning of "integration" as viewed by its proponents is explained. In the following section different arguments are advanced against the integration model. The conclusion is that such a model for Christian scientific endeavour should not be regarded as the ideal. In the case of the alternative, viz. integral Christian scholarship, Christian belief is not merely tagged on to "standard" science. The contents of the different disciplines should be transformed in the light of God's revelation, a Christian worldview, a Christian philosophy, subject philosophy and subject theory.

\section{Opsomming}

Integrasie of transformasie? "Geloof en wetenskap" of "gelowige wetenskap" as vertrekpunte vir integrale wetenskapsbeoefening

Die vraagstuk wat hier behandel word, is of die huidige integrasiemodel 'n aanvaarbare weg na werklike Christelike wetenskapsbeoefening kan wees. Om 'n antwoord op dié 
probleem te vind, word die volgende stappe gevolg. Ter inleiding word die aandag gevra vir die huidige populariteit - in die buiteland en Suid-Afrika - van die "geloof en wetenskap"benadering. Vervolgens word verduidelik wat met "integrasie" tussen geloof en wetenskap deur die voorstanders daarvan bedoel word. Daarna word aangetoon waarom dit nie die ideaal vir werklik integrale Christelike wetenskap kan wees nie. In die geval van 'n werklik integraal-Christelike beoefening van die wetenskap word die Christelike geloof nie bloot by die "standaard" wetenskap bygevoeg nie. In die lig van God se openbaring, 'n Christelike lewensvisie, 'n Christelike filosofie, vakfilosofie en vakteorie behoort die verskillende wetenskappe inhoudelik getransformeer te word.

\section{Die integrasie van geloof en wetenskap: 'n aktuele vraagstuk}

Wanneer Christenakademici van Christelike wetenskap of wetenskapsbeoefening praat, kan hulle uiteenlopende dinge daarmee bedoel. Op die gebied van die filosofie onderskei Coletto (2002) byvoorbeeld vyf verskillende modelle vir 'n Christelike beoefening van hierdie vak. Sekere idees oor wat Christelike wetenskap behels, word deur Van der Walt (2001) selfs as karikature beskou. In hierdie artikel is die fokus op slegs een populêre benadering wat as die "integrasiemodel" aangedui word. Eers word aangetoon hoe populêr die model is. Daaruit sal ook blyk wat dié benadering inhou.

\subsection{Populêr in Noord-Amerika}

In 'n oorsigtelike artikel vestig Botha $(2004: 13,14)$ die aandag op die gewildheid, veral onder die Evangelicals, van die integrasiemodel. Sy kontrasteer dit met die Reformatoriese model, wat vanuit 'n meer integrale visie die dualistiese agtergrond van hierdie integrasiemodel verwerp. Eersgenoemde wil die Christelike geloof by die gangbare wetenskap aan-/inpas, terwyl laasgenoemde daarna streef dat die geloof die wetenskap van binne uit reformeer.

Die populariteit en bedoeling van integrasievisie op die Christelike wetenskapsbeoefening word hier kortliks uit enkele geskrifte aangetoon. Dit blyk veral uit 'n reeks boeke oor verskillende vakgebiede onder die titel "... through the eyes of faith", wat deur die Christian College Coalition (CCC) uitgegee is.

- Wat 'n Christelike benadering tot die musiek betref, gaan Best (vgl. 1993:xi) duidelik van die integrasie van Christelike geloof en 
wetenskap uit. Hierteenoor is die werk van DeMol (1993) 'n poging tot 'n meer integrale aanpak daarvan.

- Ook vir Meyers en Jeeves (1987:1-4) is die sentrale probleem wat die verhouding tussen geloof en wetenskap (in casu in die psigologie) behoort te wees. Hulle wys die gedagte af dat daar konflik tussen die twee behoort te bestaan en soek na integrasie: Die Christelike geloof moet "duidelik maak" wat in die sielkunde aangaan en omgekeerd moet die psigologie die oortuigings en gedrag van Christene "verklaar". Van Belle (2005) en BoumaPrediger (1990) verdedig egter 'n meer integrale model vir 'n werklik Christelike Psigologie.

- In die werk oor die Sosiologie in dieselfde reeks (... through the eyes of faith) sê Fraser en Campolo (1992:xx) byvoorbeeld die volgende:

Thinking Christianly about society requires the delicate task of blending sociology and faith. This book is an invitation to the adventure of combining the heights of human thought about society with the depths of Christian faith. The mixture, we believe, can be an explosive concoction (my kursivering BJvdW).

- In die boek Biology through the eyes of faith deur Wright (1989) word alreeds in die voorwoord (p. $x$ ) gesê dat geloof en wetenskap nie in isolasie of opposisie teenoor mekaar staan nie, maar dat die Christenwetenskaplike se taak is om te ondersoek "how his faith and his biology fits together" (my kursivering BJvdW). Elders ( $p . x i)$ word dié taak beskryf as "a burden to bring knowledge of God's world into harmony with knowledge from God's Word" (my kursivering - BJvdW).

- Die spanning tussen die integrasie en integrale modelle is soms by dieselfde outeur merkbaar, soos byvoorbeeld in Byl (2001) se boek oor die kosmologie. Hy onderskei (p. 2) drie modelle om die probleem van die verhouding tussen die Christelike geloof en die wetenskap Kosmologie op te los naamlik: (1) konkordisme - 'n poging om die Bybel só te interpreteer dat dit met die moderne Kosmologie harmonieer; (2) die omgekeerde metode, naamlik om die moderne Kosmologie by die Woord van God te probeer aanpas; en (3) die komplementêre model, waarvolgens die Kosmologie en die Christelike geloof (vir Byl dieselfde as die Teologie) onafhanklik van mekaar bestaan, omdat hulle met verskillende soorte probleme te make het. Eersgenoemde moet vrae soos Wanneer? en Hoe? (het die wêreld ontstaan) beantwoord, terwyl laasgenoemde die Wie het? en Waarom is? (die 
aarde geskep) moet antwoord. Byl (2001:3-13) kritiseer posisies (1) en (3) en verkies (2), omdat hy ten volle die gesag van die Skrif wil handhaaf.

Hy staan tog wel ook die integrasiemodel voor. Hy praat (p. 215) byvoorbeeld van die interaksie tussen Teologie en Kosmologie of die versoening tussen die Skrif en die wetenskap. Soms is die spanning in sy denke duidelik as dit lyk (p. 224, 225) asof hy die integrasiemodel verwerp, omdat dit vir hom bloot - en tereg neerkom op die akkommodering van die Christelike geloof aan die Kosmologie. Sy voorwaarde is dat daar meer aandag aan differensiasie gegee moet word want "only then can genuine integration be attained" (p. 225). Hy wil seker maak dat by die integrasie van die twee pole (Teologie en Kosmologie) die Teologie prioriteit sal ontvang - die Kosmologie moet by die Teologie (met die Bybel vereenselwig) aanpas en nie die omgekeerde nie.

Teenoor al ses bogenoemde voorbeelde van integrasie is daar egter skrywers soos Clouser (1991), Fowler (2001), Kok (2004) en Sinnema (2001) wat duidelik 'n meer integrale benadering (die Reformatoriese model) voorstaan. Heelwaarskynlik is daar ook nog 'n tussengroep, soos Van Brummelen (2001) en Zylstra (1997) wat met hulle faith-based learning nie 'n duidelike keuse tussen die integrale en integrasiemodelle gemaak het nie.

Wat is die situasie in Suid-Afrika?

\subsection{Voorbeelde van integrasie in Suid-Afrika}

Ek beperk my slegs tot die Potchefstroom-kring, omdat dié Universiteit tot onlangs (2003) nog 'n eksplisiet Christelike karakter gehad het.

- Op 'n meer populêre vlak blyk die verskil tussen Van der Walt (2004:17-19) en Erasmus en Kruger (2004:30-32) duidelik oor hoe die verhouding tussen geloof en wetenskap beskou behoort te word. Van der Walt verwerp dit as 'n onnodige dilemma en praat gewoon van gelowige wetenskap (in die geval van sowel Christene as andersdenkendes), terwyl die ander twee skrywers die komplementêre model (vgl. hierbo) handhaaf. Daarvolgens moet die Christelike geloof die antwoord gee op Wie die aarde geskep het, terwyl die (evolusionistiese) wetenskap moet sê hoe dit gebeur het.

- Op akademiese gebied (in die Skool vir Filosofie van die Noordwes-Universiteit) kom die teenstelling duidelik na vore in 
twee onlangse meestersgraadverhandelinge. Coletto (2002:114128 ) is ' $n$ voorstander van die meer integrale model vir 'n Christelike filosofie. Kruger (2003:134-137) daarenteen neig sterk na die integrasiemodel.

Die gewildheid van die integrasiemodel blyk ook daaruit dat daar op die Potchefstroomkampus van die nuwe Noordwes-Universiteit 'n Sentrum vir Geloof en Wetenskap bestaan. 'n Integrale model sou só 'n sentrum eerder "Die Sentrum vir gelowige (of geloofsbegronde) Wetenskap" noem.

\subsection{Probleem en hipotese}

Uit die voorafgaande blyk dat die twee benaderings tot Christelike wetenskap (integrasie en transformasie) verskil. Integrasie probeer geloof en wetenskap versoen, terwyl transformasie van mening is dat elke wetenskap - die Christelike sowel as die neutrale of sekulêre - nie anders kan as om van (voorwetenskaplike) geloofsveronderstellings uit te gaan nie, omdat geloof ' $n$ integrale deel daarvan vorm. Eersgenoemde visie is dus dié van "geloof en wetenskap", terwyl laasgnoemde standpunt dié is van "gelowige wetenskap"; eersgenoemde wil die sekulêre wetenskap van buite af kersten, terwyl laasgenoemde dit van binne uit wil transformeer.

Die probleem is: Watter een van die twee is die korrekte benadering? My hipotese is dat vir die transformasionele model gekies behoort te word. Om die veronderstelling te kan bevestig, word vervolgens die volgende drie vrae beantwoord: Wat presies behels dié integrasiemodel? Wat is die (historiese) oorsprong daarvan? Kan dit 'n prinsipiële toets deurstaan?

\section{Wat die integrasiemodel inhou}

\subsection{Wat word nie bedoel nie}

Die volgende vier sake is belangrik:

- As gevolg van oorspesialisering is dit dringend noodsaaklik om op interdissiplinêre wyse die gefragmenteerde wetenskaplike kennis te probeer integreer. Interdissiplinêre dialoog kan Christenwetenskaplikes help om bewus te bly van die breëre verbande en ook reduksionisme te bekamp. Reduksionisme is 'n neiging van die meeste wetenskaplikes om alles vanuit hulle eie vakperspektief, byvoorbeeld die ekonomiese, psigologiese, ensovoorts te verklaar. Om die eenheid te midde van die 
komplekse diversiteit te ontdek, is egter iets anders as die integrasie van geloof en wetenskap.

- Verwerping van die integrasiemodel beteken ook nie die ontkenning van die noodsaaklikheid van dialoog met wetenskaplikes van ander oortuigings as die Christelike nie.

- Die integrasiemodel impliseer ook nie dat dit nie belangrik is om die aard van geloof en wetenskap, religie en rasionaliteit as twee verskillende, maar nie van mekaar geïsoleerde menslike funksies, asook hulle onderlinge verhouding deeglik te bestudeer nie.

- As gevolg van die sondegebrokenheid van die Christenwetenskaplike se lewe, mag hy/sy dalk nie doelbewus daarna streef om sy/haar geloofsoortuiging op wetenskaplike gebied (en alle ander lewensterreine) tot vergestalting te bring nie. In baie gevalle ontbreek ook die nodige lewensbeskoulike en filosofiese geskooldheid om dit te kan doen. In sulke gevalle sal 'n aansporing tot integrasie egter nie help nie.

Wat word dan wel met "integrasie" bedoel?

\subsection{Die integrasie tussen geloof in wetenskap}

Integrasie kan verskillende vorms aanneem. Sinnema (2001:188191 ) bied 'n nuttige samevatting. Die integrasiemodel kom volgens hom op die volgende neer:

... in the integration model it is assumed that the Christian faith and academic disciplines are two separate components whose relationship needs to be recognized and developed. Though sometimes it is agreed that for God there is a unity of truth, for humans, at least faith and learning are separated and need to be integrated (Sinnema, 2001:189).

Dit is interessant dat vir baie van die voorstanders van hierdie model die einddoel van integrasie blykbaar is dat die Christelike geloof die wetenskap sal "deurdring" of transformeer. Sommige integrasioniste beklemtoon ook dat dit kritiese integrasie moet wees en nie kritieklose akkommodasie nie. Die belangrike punt waarop Sinnema egter die aandag vestig, is of so 'n eindpunt wel bereik kan word indien die uitgangspunt van alle integrasievisies is dat die Christelike geloof en die wetenskap(pe) twee totaal afsonderlike domeine van kennis is.

Sinnema (vgl. ook Heie \& Wolfe, 1987) toon ook aan dat daar verskillende strategieë bestaan om die integrasiemodel te im- 
plementeer. Dit hang af van die wyse waarop die verhouding tussen geloof en wetenskap gesien word. Sinnema noem die volgende moontlikhede: geloof en wetenskap verkeer in konflik; hulle oorvleuel met mekaar; hulle is in gesprek/interaksie met mekaar; of hulle moet met mekaar geïntegreer word.

Enkele van die voorstanders van die integrasiemodel gee wel toe dat wetenskapsbeoefening nie sonder geloofsvoorveronderstellings geskied nie. Hulle bly egter nogtans die basiese model handhaaf deur te sê dat Christenwetenskaplikes die aard van die integrasie moet ontdek en bevorder.

Die tweede vraag was wat die historiese oorsprong van die integrasiemodel is.

\section{Die historiese agtergrond van die integrasiebeskouing}

Histories besien, is die integrasiedenke nie iets nuuts nie - dit het 'n lang geskiedenis van byna 2000 jaar. Dit begin by die vroegChristelike (Patristiese) denke (vgl. Wolters, 1990 en Van der Walt, 1976 en 1986). Die kenteoretiese probleem van geloof en wete loop verder deur die Middeleeue en die worsteling daarmee word voortgesit gedurende die 16de-eeuse Reformasie (vgl. Van der Walt, 2005:9-11) tot vandag toe (vgl. Van der Walt, 2005:17-22).

\subsection{Die gevolg van dieperliggende dualismes}

Dit is belangrik om te begryp dat hierdie kenteoretiese probleem gewortel is in 'n dieperliggende ontologiese dualisme en 'n antropologiese digotomie, wat immers bepalend is van 'n mens se kenteorie.

Van der Walt (2000b:130 e.v.) toon aan dat die meeste Christelike lewensvisies op 'n inherente dualisme gebou is. Omdat Christene van die sondeval en gebrokenheid van die skepping bewus is, is hulle geneig om 'n deel van die skepping te depresieer, gering te skat of selfs as inherent sleg te beskou. Volgens die Skrif is geen faset van die skepping egter òf heeltemal boos òf volmaak goed nie. Alles in die skepping het na die sondeval deel aan die slegte en as gevolg van Christus se verlossing, ook aan die goeie. Die grens tussen goed en kwaad lê nie êrens tussen bepaalde fasette of gebiede in die skepping nie. Die onderskeid goed-kwaad is 'n religieuse onderskeid, wat die rigting van die skepping, naamlik gehoorsaamheid of ongehoorsaamheid aan God se wet, aandui. Dit is nie ' $n$ ontologiese skeiding wat die struktuur van die skepping betref nie. 
Die skepping mag daarom nie in 'n bonatuurlike, sakrale terrein van genade en 'n natuurlike, sekulêre terrein verdeel word nie. Dit is die geval van baie Christelike lewensvisies en teologieë. Dié dualistiese twee-terreinleer is ' $n$ onbybelse gedagte. Volgens die Skrif staan genade nie teenoor die natuur nie, maar teenoor God se toorn. Verlossing is dus nie iets aparts van die skepping nie, maar is vir die skepping bedoel - verlossing van die skepping.

\subsection{Verskillende dualistiese lewensvisies}

In die loop van die lang geskiedenis van die Christendom het verskillende soorte dualismes ontstaan, wat vanaf die vroeë Christendom tot vandag voorkom. Die vyf basiese tipes is die volgende (vgl. Van der Walt, 2000b:134 e.v): verlossing teenoor die skepping; verlossing langs die skepping; verlossing bokant die skepping; verlossing vanuit die skepping en verlossing in of vir die skepping, om dit te herstel en te vernuwe. Van der Walt (vgl. 2000b:134-138) toon aan hoe hierdie grondliggende vertrekpunte alle aspekte van die mens se denke en aktiwiteite bepaal. Hierdie vertrekpunt beslis ook hoe 'n Christen teenoor die wetenskap staan.

\subsection{Die implikasies vir Christelike wetenskapsbeoefening}

Die implikasies van die vyf lewensvisies is die volgende:

- Volgens verlossing teenoor die skepping sal 'n Christen homself teenoor die wetenskap opstel. Geloof het nie wetenskaplike begronding/verduideliking of bewyse nodig nie. 'n Mens is 'n gelowige of 'n wetenskaplike.

- Volgens die visie van verlossing langs die skepping bevind die Christengelowige hom langs die wetenskap. Dit beteken dat hy/sy Sondag 'n gelowige in die kerk mag wees, maar nie in sy aktiwiteite van Maandag tot Saterdag nie. Die twee "gebiede" van sy lewe bestaan parallel langs mekaar. Hiervolgens is ' $n$ mens ' $n$ gelowige en 'n wetenskaplike.

- Die implikasie van verlossing bokant die skepping as vertrekpunt is dat die Christelike geloof iets hoër of bokant die wetenskap is. Van buite af mag 'n Christen dus probeer om die wetenskap te beïnvloed. Dit kan gebeur deur middel van die byvoeging van morele waardes - 'n etiese "sousie" by die standaardwetenskap. Maar omdat dit van buite af kom, kan dit nie van binne-uit werklik die sekulêre wetenskap verander nie. In ander gevalle word vanuit die Teologie (wat vanselfsprekend Christelik sou wees) 'n teologiese perspektief vir die verskillende vakke uitgewerk. Ook 
hierdie teologiese "sousies" kan nie tot 'n integrale Christelike ekonomie, ekologie, ensovoorts lei nie - dit bly bloot 'n versiersuiker of vernislagie bo-oor sekulêre idees.

- Volgens die vertrekpunt van verlossing vanuit die skepping aanvaar of "doop" die Christen eenvoudig die standaard, sekulêre wetenskap. Indien dit van hoë gehalte is (vgl. die hedendaagse klem op excellence), dan sou dit vanselfsprekend ook Christelik wees. ' $n$ Christelike benadering tot die wetenskap maak dus nie werklik 'n verskil nie en is dus nie nodig nie.

- Die laaste standpunt, verlossing in/vir die skepping, is nie die eenvoudigste nie, omdat die werklikheid self en kennisverwerwing nie eenvoudig is nie. Myns insiens is so 'n standpunt die korrekte. Omdat wetenskaplike werk nie vanselfsprekend goed, naamlik gehoorsaam aan God se verordeninge, is nie (visie 4), of vanselfsprekend net uit die bose nie (visie 1), kan 'n Christenwetenskaplike dit nie eenvoudig net so aanvaar of verwerp nie. Dit moet hervorm word. Hy/sy kan ook nie daarmee tevrede wees om Christen en wetenskaplike te wees nie (visie 2 en 3), maar moet daarna streef om werklik 'n Christenwetenskaplike te wees - iemand wat integraal lewe en nie met 'n skisofrene bestaan vrede het nie.

\subsection{Gevolgtrekking}

Die integrasiemodel kan sowel posisie 2 as 3 hierbo inneem. Die baie kort historiese oorsig toon dus aan dat die integrasiemodel nie 'n heeltemal nuwe benadering tot die probleem van Christelike wetenskap is nie. Dit is ook nie die enigste benadering gedurende die lang Christelike tradisie nie. Nog belangriker is egter die derde vraag, naamlik of dit 'n meer prinsipiële toets kan slaag.

\section{Die integrasiemodel prinsipieel beoordeel}

Vir iemand wat werklik integrale Christelike wetenskapsbeoefening nastreef, is die integrasiemodel om die volgende redes onvoldoende:

\subsection{Die aard van die wetenskap self maak ware Christelike wetenskap moontlik}

Heyns (1999:110) stel tereg dat 'n mens nie soos die integrasioniste iets (die Christelike geloof) by die "gewone" wetenskap hoef by te voeg om dit Christelik te maak nie. Die prespektiewiese aard van die wetenskap self, naamlik die feit dat dit 'n teoretiese uitwerking van 'n 
bepaalde voorwetenskaplike werklikheidsvisie is, maak dit moontlik. Omdat dit so 'n belangrike punt is, word Heyns breedvoerig aangehaal:

Soms word van voorstanders van Christelike wetenskap gevra om die 'Christelikheid' van hul wetenskap aan te toon. Die Christen-wetenskaplike moet dan aantoon dat sy wetenskap 'anders' lyk as hoe die res van die wetenskaplike gemeenskap die saak sien. Die veronderstelling is dat 'Christelikheid' iets anders of meer toevoeg aan die blote neutrale wetenskap soos almal dit ken. Indien 'n Christen hierdie (valse) uitdaging aanvaar, sal hy probeer aantoon dat daar bykomende waarhede bestaan waaroor hy as Christen alleen beskik. Dit is byvoorbeeld iets wat die teologie vir hom kan gee waarmee hy dan sy wetenskap Christelik kan maak. In so 'n geval kan geredeneer word dat die Bybel 'n bykomende soort kenbron vir die wetenskap sal wees. Hierdie benadering berus egter op die valse aanname dat die Christelike karakter van die wetenskap in terme van 'n byvoeging tot blote of normale wetenskap gesien word. Hiermee word in feite eintlik al toegegee dat Christelikheid niks te make het met die wetenskap nie want Christelikheid word 'n blote aanplaksel aan die wetenskap. Hierdie soort Christelike wetenskap eindig dan ook in 'n blote Christelike sousie wat oor die andersins sekulêre wetenskap gegooi word. Die alternatief tot die 'Christelike-sousie-teorie' is om te redeneer dat die struktuur van die wetenskap self die ruimte laat vir 'n Christelike wetenskap (Heyns, 1999:110).

\subsection{Geloof lê ten grondslag aan alle wetenskaplike werk}

Selfs ten spyte van die gebrokenheid van ons bestaan, is geloof en wetenskap nie twee afsonderlike pole van 'n mens se ervaring nie. Geloof en wetenskap is nie geskei nie, selfs nie wanneer die invloed van die geloof nie direk sigbaar is nie. Die Woord van God en die Reformatoriese tradisie in navolging daarvan, leer dat 'n mens se religieuse oortuigings die rigting of koers van jou hart is en jou hele lewe ten goede of ten kwade beïnvloed.

Soos hierbo geblyk het, is religieuse voorveronderstellings 'n inherente, integrale deel van elke wetenskaplike aktiwiteit en resultaat. Elke dissipline is gegrond op (onbewese, gelowig aanvaarde) ontologiese, antropologiese en epistemologiese uitgangspunte, wat ook die wetenskaplike teorieë, metodologieë (bv. seleksie van gegewens) en die doel van die wetenskap(pe) bepaal. Clouser (1991:3) sê byvoorbeeld "... one religious belief or another controls theory making in such a way that the contents of the 
theories differ depending on the contents of the religious belief they propose".

Sinnema (vgl. 2001:193) voeg nog drie belangrike opmerkings hierby. In die eerste plek gaan religie/geloof nie net oor God/gode of die "bonatuurlike" nie, maar ook oor hierdie wêreld. Só byvoorbeeld moet iemand glo in die inherente orde van die werklikheid wat hy bestudeer.

Die sekulêre wetenskap is nie minder as die Christelike op 'n afvallige geloof gegrond nie en daarom is die botsing nie (soos die integrasioniste dit dikwels voorstel) dié tussen geloof en wetenskap nie. Dit is ten diepste 'n botsing tussen twee of meer gelowe. Heyns (1999:120) stem saam:

Dit beteken dat die stryd in werklikheid nie bestaan tussen geloof en wetenskap nie, maar tussen verskillende wetenskaplike stelsels wat elk uit sy eie religieuse grond kom. Dit beteken dat meerdere religieë binne die sfeer van die wetenskap bestaan. Wetenskap vind plaas te midde van die stryd tussen religieë.

Hieruit vloei voort dat geloof en wetenskap nie geïntegreer hoef te word nie, omdat hulle alreeds geïntegreerd is. Daar moet eerder gevra word watter soort geloof ten grondslag van 'n spesifieke wetenskap lê.

\subsection{Die grondliggende dualisme kan nooit werklik oorwin word nie}

Hoewel die doel van die integrasiemodel die eenheid van geloof en wetenskap (gelowige wetenskap) is, kan dit moeilik slaag. Die dualistiese uitgangspunt (die gedagte dat geloof iets buite of vreemd aan die wetenskaplike bedryf is) kortwiek dié lofwaardige doel. Solank die siening gehandhaaf bly dat die Christelike geloof iets ekstrinsiek tot akademiese werk is - wat 'n "versoening" tussen die twee entiteite noodsaak - sal Christelike wetenskap in die egte sin van die woord 'n lugspieëling bly. Volgens Sinnema (2001:194) is die meeste wat bereik kan word 'n swak dualistiese integrasie.

\subsection{Struktuur en rigting word verwar}

Die bedoeling van die integrasioniste is goed. In die hedendaagse wêreld, waar die sekulêre denke geloof - alle ander gelowe behalwe hulle eie sekulêre geloof - en wetenskap probeer skei en die wetenskap as gevolg van oorspesialisering gefragmenteerd geraak 
het, probeer die voorstanders van integrasie weer eenheid skep. Hulle basiese fout is egter dat hulle eers die skeiding (dualisme) goedkeur om dit daarna te probeer oorkom. In die woorde van Spykman (1992:67):

Dualism gives the spiritual antithesis ontological status by defining some parts, aspects, sectors, activities or realms of life (the ministeries of the church [die Christelike geloof]) as good and others (politics [die wetenskap]) as less good or even evil. Dualism grants sin a built-in ontological status ... At bottom, therefore, dualism may be defined as a confusion between structure and direction ... the (religious) antithesis is read back into the very structure of creation.

\subsection{Alleen gedeeltelike integrasie moontlik}

Ook die voorstanders van die integrasiemodel sal moet toegee dat volledige integrasie tussen die Christelike geloof en die gangbare wetenskappe nie moontlik of wenslik is nie. Die bestaande wetenskapsbeoefening, wat meestal gegrond is op die sekulêre geloof, naamlik dat God nie bestaan nie en sy verordeninge nie relevant is nie, is in baie gevalle regstreeks in konflik met die mees basiese punte van die Christelike geloof. Om dié rede is die integrasioniste gewoonlik geneig om na "ooreenkomste" tussen die Christelike geloof en die gangbare wetenskappe te soek. Die resultaat is nogtans slegs 'n gedeeltelike integrasie.

\subsection{Die rol van die teologiese wetenskap in die integrasie}

Heel dikwels word die integrasie tussen geloof en wetenskap vereng tot die integrasie tussen Teologie en die ander wetenskappe (vgl. Byl, 2001). Wedersydse "bevrugting" word voorgestel: Die Teologie moet die ander dissiplines beïnvloed en omgekeerd moet hulle weer die Teologie verryk. Teen interdissiplinêre kontak as sodanig het hierdie artikel nie beswaar nie - dit is uiters noodsaaklik (vgl. 2.1.1). Binne die konteks van die integrasiemodel bestaan daar egter ernstige gevare.

In die eerste plek (vgl. Sinnema, 2001:195) bly die invloed van die Teologie ekstrinsiek - geen intrinsieke Christelike benadering tot die nie-teologiese vakke is moontlik nie. 'n "Teologiese ekonomie" is byvoorbeeld nog nie 'n Christelike ekonomie nie, maar bloot 'n verteologiseerde ekonomie.

In die tweede plek gaan dit saam met 'n baie algemene verkeerde visie op die Teologie, naamlik dat dit met geloof/religie vereenselwig 
word. Geloof in God se openbaring is egter iets voorteoreties en dus ook voorteologies, terwyl Teologie die teoretiese besinning op geloof is. Die Teologie is ook nie bloot vanselfsprekend Christelik omdat dit God, die geloof of die Skrif as veld van ondersoek het nie. Dit is nie die veld van ondersoek nie, maar die perspektief van waaruit 'n wetenskap beoefen word, wat dit Christelik maak of nie. (Vgl. Van der Walt, 2005:158-165 vir 'n meer korrekte visie op die taak en plek van die Teologie in die beoefening van Christelike wetenskap.)

\subsection{Die integrasiemodel bied nie 'n oplossing vir die postmodernistiese bedreiging nie}

Die gevolgtrekking by die historiese ondersoek was (vgl. 3.4) dat die integrasiemodel reeds baie oud is. In hierdie prinsipiële besinning moet ten slotte gestel word dat dit ook verouderd is en nie in pas met die tyd is nie. Die integrasiemodel gaan blykbaar nog steeds daarvan uit dat die wetenskap iets neutraals is wat gevolglik met die Christelike geloof geïntegreer kan word.

Die heersende geestestroming vandag is egter die postmodernisme. Hierdie stroming staan nie neutraliteit voor nie. Na ongeveer vier eeue, waarin die gedagte van 'n waardevrye, objektiewe, neutrale wetenskap hoogty gevier het, word vandag uiteindelik erken dat so iets onmoontlik is.

Aan die een kant sal postmoderniste die Christene wat hulle geloof met hulle wetenskap wil integreer, verbaas aankyk - die twee dinge is mos onafskeidelik verbonde. Aan die ander kant sal Christelike integrasioniste moet besef dat hulle vandag in 'n totaal ander geestesklimaat leef en wetenskap beoefen. In plaas daarvan om 'n dooie perd (die modernistiese neutraliteitsidee) te slaan, sal hulle eerder nuwe wapens moet bedink as teenvoeter vir hierdie nuwe, springlewendige en baie gevaarliker mededinger van 'n Christelike wetenskap - die postmodernisme.

$\mathrm{Na}$ die historiese beligting en prinsipiële kritiek moet nou na 'n alternatief vir die integrasiemodel gesoek word.

\section{Die alternatief van 'n integrale Christelike weten- skapsbeoefening}

'n Werklik integrale, Christelike wetenskapsbeoefening is veel meer gekompliseerd en moeiliker as die eenvoudige integrasiemodel. Van der Walt (vgl. 2005:150 e.v.) noem vyf "boustene" as vereistes: Dit moet gedoen word by die lig van God se openbaring; dit vereis 'n 
Christelike lewensvisie; 'n Christelik-filosofiese agtergrond; 'n vakfilosofie en 'n vakteorie. Ter verduideliking word alleen oor die eerste drie iets meer gesê, aangesien hulle gewoonlik die meeste verwaarloos of verkeerd verstaan word by die integrasioniste.

\subsection{Die "lig" van God se openbaring vir die wetenskap}

Die integrasiemodel is geneig om alleen die integrasie van een faset van God se openbaring (dié in die Bybel) met die wetenskap te beklemtoon. Die Reformatoriese benadering onderskei en beklemtoon in God se één openbaring drie fasette, naamlilk in die skepping, in die Skrif en in Christus. Die term skeppingsopenbaring is nie heeltemal bevredigend nie, omdat die drievoudige openbaring alleen deur die skepping plaasvind - ook in die geval van die Bybel in menslike taal, terwyl ook Christus mens geword het.

\subsubsection{Drieërlei openbaring en wetenskap}

God se openbaring deur die skepping bied nie, soos dikwels veronderstel word, alleen inligting oor sy aard nie (vgl. Rom. 1:20). In die skepping word ook sy wil vir al die geskape dinge geopenbaar - so duidelik dat ook dié wat nie in Hom glo nie dit kan ken (vgl. Rom. 2:14,15). God se skeppingswoord bied 'n komplekse stel wette waardeur Hy die skepping gemaak het, orden en in stand hou. Hulle is nie bloot natuurwette nie, maar die uitdrukking van God se wil vir die struktuur van die verskillende skepsele.

Die skepping self vertoon hierdie wette of ordeninge vir die verskillende dinge alleen op 'n latente manier, deur die manier waarop die geskape dinge funksioneer. Uit hierdie ordelikheid van die skepping moet wetenskaplikes God se orde vir die skepping probeer aflei, verstaan en formuleer.

Gewoonlik gebeur dit soos volg: 'n wetenskaplike bestudeer gelyksoortige stande van sake op sy vakgebied; hy bemerk 'n basiese, ordelike patroon daarin en kom tot die gevolgtrekking dat daar "wet(te)" is wat sulke reël- of wetmatigheid bepaal en hy probeer dan dié wet(te) beskryf. Sulke wetenskaplike formulerings bly egter feilbare benaderings van God se wette, wat goddelike gesag het.

Terwyl die skeppingsopenbaring latent is en van nie-talige aard (vgl. die "sprakelose spreke" van Ps. 19:4), is God se Woordopenbaring in menslike taal geskryf. Die skopus van die Skrif is ook meer beperk - primêr op God se verlossingsboodskap vir die skepping gerig. Daarom herhaal dit gewoonlik ook nie die dinge wat God deur 
sy skepping openbaar nie. Wetenskaplikes moes byvoorbeeld self die struktuur van die atoom ontdek.

Op selektiewe wyse artikuleer die Skrif egter sommige temas uit God se skeppingsopenbaring. 'n Politieke wetenskaplike kan byvoorbeeld deur sy bestudering van politieke verhoudings ontdek wat geregtigheid is, maar die Bybel openbaar ook die aard van ware geregtigheid. Om dié rede kan gesê word dat die Bybel soos 'n bril is wat die mens se deur sonde verswakte oë help om God se skeppingsopenbaring duideliker te kan "lees".

Omdat die mens as gevolg van die sonde doof en blind geword het vir die twee vorige vorme van God se openbaring, kom God se openbaring in die derde plek nog duideliker na vore in die vleeswording van Jesus Christus. Hy herinner ons weer aan God se skeppings- en Woordopenbaring en as voorbeeld leef Hy soos die mens behoort te leef - volgens God se wil.

Omdat die integrasioniste veral die Bybel met die wetenskap probeer integreer, word hier gestel hoe die Bybel nie en wel gebruik mag word.

\subsubsection{Hoe die Bybel nie gebruik behoort te word nie}

'n Mens kan óf te min van die Bybel verwag deur dit as iets net vir die geestelike lewe in jou hart toe te sluit, sonder betekenis vir die res van die lewe, óf te veel, deur te probeer om daaruit antwoorde op al jou wetenskaplike vrae te vind. Die integrasiemodel waarin God se skeppingsopenbaring glad nie of onvoldoende figureer, neig na laasgenoemde uiterste. Sowel diegene "met die Bybel in die hart" as die ander "met die Bybel in die hand", wat daarvan 'n handboek in plaas van 'n lig vir die wetenskap maak, fouteer egter. Oor laasgenoemde se verkeerde gebruik van die Bybel moet die volgende twee opmerkings gemaak word.

'n Mens mag nie probeer om alles met teksbewyse (proof-texting) uit die Bybel te bewys nie. Skrifgedeeltes mag nie willekeurig uit verband aangehaal word nie. Verder vereis Christelike wetenskap nie altyd die eksplisiete aanhaal van spesifieke Bybeltekste nie. Dikwels is ' $n$ algemene verwysing na ' $n$ Skrifgedeelte of ' $n$ tema uit die Skrif voldoende. Veel belangriker vir die wetenskap is dat 'n mens se omvattende lewensvisie (werklikheidsbeskouing) op die Bybelse boodskap gegrond is (vgl. 5.2).

Die Bybel is dus nie in die eerste plek 'n addisionele bron van kennis wat met die wetenskaplike kennis geïntegreer moet word nie. Dit is 
eerder 'n lig op die pad van kennisverwerwing. Die "pad" is die skepping wat noukeurig bestuur moet word en die Bybel verlig dit en laat ' $n$ mens die kontoere van God se skeppingsopenbaring beter verstaan. Soos in die geval van 'n mynwerker met 'n lamp op sy voorkop, kyk die Christenwetenskaplike nie in die lig van God se Woord om daar die antwoorde op sy vrae te vind nie, maar hy bestudeer by dié lig die aardse werklikheid.

\subsubsection{Hoe die Bybel wel in die wetenskap gebruik mag word}

Sinnema $(2001: 203,204)$ toon aan hoe die Skrif op verskillende vlakke 'n verligtende, normatiewe rol in Christelike wetenskaplike aktiwiteite kan speel.

- Volgens die Skrif se verlossingsfokus roep dit die mens op tot geloof in en gehoorsaamheid aan die enige ware God. Dié geloof moet gestalte kry in alles wat elke mens doen - ook sy wetenskaplike werk.

- Die Bybel leer ook die noodsaaklikheid van en bied die basiese boustene vir 'n Christelike lewensvisie (sien 5.2). Van hierdie boustene is die sentrale Bybelse boodskap van skepping, sondeval, verlossing en voleinding.

- Die Bybel bied verder ook riglyne of norme vir spesifieke vakgebiede. Hierdie norme kan wel deur noukeurige waarneming uit God se skeppingsopenbaring ontdek word, maar sommige van hulle word eksplisiet in die Bybel herhaal. So byvoorbeeld leer die staatkundige of politokoloog in die Skrif van geregtigheid, die ekononoom wat rentmeesterskap beteken, die sosioloog dat die essensie van die huwelik wedersydse trou is, die psigoloog wat ware menswees behels, ensovoorts.

- Die Woord van God leer ook sekere deugde wat van toepassing is op goeie wetenskapsbeoefening, soos intellektuele integriteit, 'n ondersoekende gees, geduld, nederigheid en regverdigheid teenoor diegene van wie 'n mens verskil.

- Daarbenewens is 'n nie-normatiewe gebruik van die Skrif ook moontlik. Afgesien van sy verlossingsboodskap, gee dit ook insidentele inligting, wat vir verskillende vakgebiede van belang mag wees, maar nie normatief van aard is nie. Hoewel toelaatbaar, maak die gebruik daarvan - soos sommige integrasioniste meen - nog nie 'n wetenskap Christelik nie. Voorbeelde daarvan is dat 'n Christelike argitek mag belangstel in die struktuur van Salomo se tempel, 'n dieetkundige in die eetgewoontes van die antieke Israel, 'n mediese wetenskaplike in 
die siektes en medisyne waarvan die Bybel melding maak, 'n skeepsingenieur in hoe Noag se ark gelyk het, 'n ekonoom in die destydse handelsgebruike of 'n taalkundige in die Hebreeuse en Griekse taal.

\subsection{Die verruiming van 'n Christelike lewensvisie}

Die tweede noodsaaklike bousteen vir 'n integrale Christelike wetenskapsbeoefening (vgl. 5) is 'n integrale, holistiese lewensvisie. Dit is nie iets wetenskapliks nie, dog voorwetenskaplik van aard. Dit bepaal hoe die mens na alles rondom hom kyk en wat hy daarmee doen. 'n Lewensvisie word deur verskillende mense verskillend omskryf - 'n eenvoudige definisie is die volgende: Dit is die grondliggende, konseptuele raamwerk waardeur 'n mens na die totale werklikheid (God, die skepping en God se verordeninge vir die skepping) kyk, dit interpreteer en sin daarvan maak.

'n Lewensvisie is dus 'n perspektief op die totale werklikheid. Omdat God vir Christene 'n werklikheid is, sluit hulle lewensvisie, behalwe 'n visie op die aardse werklikheid, ook 'n Godsidee en 'n idee van God se wette wat vir die aardse werklikheid geld, in. Die idee van God word nie, soos in die geval van die integrasioniste, agterna "bygevoeg" nie. Volgens die Bybel mag die skepping nooit as iets selfstandig, los van sy Skepper beskou word nie.

Die skepping is dus 'n eenheid en mag nie in 'n profane of sekulêre (laere) terrein en 'n sakrale, heilige (hoëre) gebied verdeel word nie. Volgens die Skrif geskied die ontwikkeling van die skepping deur die volgende fases: skepping, sondeval, verlossing en voleinding. 'n Mens sou dit ook kan beskryf as formasie, deformasie, reformasie en konsummasie.

Aangesien vanuit Christelike perspektief alreeds heelwat oor die noodsaaklikheid en eienskappe van 'n lewensvisie in die algemeen en spesifiek 'n Christelike lewensvisie geskryf is, ${ }^{1}$ hoef hier nie meer daaroor gesê te word nie. Sinnema (vgl. 2001:199-201) toon aan hoe die idee van God, skepping, sondeval, verlossing en 'n nuwe skepping op reële, konkrete wyse die wetenskapsbeoefening van 'n Christen kan beïnvloed.

1 Omdat 'n Christelike lewensvisie van so 'n kardinale belang is in enige poging tot 'n Christelike wetenskap, noem ek slegs die volgende bronne: Colson \& Pearcey (1999), Chaplin (1986), Goudzwaard (1984), Marshall e.a. (1989), Marshall \& Gilbert (1998), Naugle (2002), Pearcey (2004), Sire (1976 en 1990), Van der Walt (2000c), Walsh \& Middleton (1984) en Wolters (1985). 


\subsection{Verdieping deur 'n Christelike filosofie}

Dit is die derde vereiste vir 'n integrale aanpak. Terwyl 'n lewensvisie iets voorwetenskaplik is en die meeste mense bewustelik of meestal onbewus volgens ' $n$ bepaalde visie dink en optree, is filosofie die wetenskaplike, sistematiese besinning oor die eie en ook oor ander lewensvisies. 'n Christelike filosofie sal dus ook bepaalde idees oor God, die skepping en sy verordeninge vir die skepping insluit (filosofiese ontologie). Verder sal dit 'n eie mensbeskouing (antropologie) en kenleer (epistemologie) handhaaf. Al hierdie afdelings van die filosofie is van belang vir die ander vakgebiede om 'n Christelike perspektief op hul eie terrein uit te bou. 'n Christelike filosofie is dus 'n derde, onontbeerlike bousteen vir integrale Christelike wetenskap op enige terrein.

Aan die laaste twee boustene, naamlik 'n spesifieke vakfilosofie en vakteorie word nie hier aandag gegee nie, omdat daarmee die terrein van die verskillende dissiplines betree word.

\subsection{Gevolgtrekking}

So 'n visie op Christelike wetenskapsbeoefening verskil van die meeste integrasiemodelle (vir 'n diagrammatiese verduideliking, vgl. Van der Walt, 2005:149 en 151). Die basiese boustene behoort God se openbaring, 'n Christelike lewensvisie, 'n Christelike filosofie, vakfilosofie, vakteorie en vakwetenskap (as finale resultaat) te wees. Die integrasioniste slaan die Christelike lewensvisie en filosofie oor - dikwels ook die vakfilosofie en -teorie - om 'n regstreekse integrasie tussen die geloof in God se openbaring (meestal net die Bybel of die Teologie, wat verkeerdelik met die Skrif geïdentifiseer word) en die betrokke wetenskap te probeer bewerk. Al die "filters" wat tussenin lê - inherente fasette van die normale wetenskaplike proses - word dus oorgeslaan. Die vraag kan dus gestel word of hulle, op die keper beskou, nie die neutraliteitsidee gekoop het en dit weer met die Bybel probeer neutraliseer nie.

\section{Benamings vir integrale Christelike wetenskap}

Twee sake vra ten slotte nog die aandag, naamlik hoe so 'n integrale aanpak van Christelike wetenskap die beste benoem kan word, en hoe so 'n tipe Christelike wetenskapsbeoefening prakties te werk moet gaan. 


\subsection{Onbevredigende name}

'n Naam moet so duidelik as moontlik 'n saak tipeer. Die volgende name lyk nie ideaal nie:

- Dit kan nie bloot gelowige of geloofsgebaseerde wetenskap genoem word nie (vgl. Zylstra, 1997 en Van Brummelen, 2001), want so ' $n$ benaming is nie net op Christelike wetenskap van toepassing nie. Geen wetenskap is sonder geloofsvoorveronderstellings nie.

- Bybelse wetenskap is ook nie 'n geskikte term nie, omdat God se skeppingsopenbaring 'n belangrike rol in enige wetenskapsbeoefening speel. Verder beroep die meeste Christene hulle op die Bybel.

- Christelike wetenskap of 'n Christelike perspektief op die wetenskap is 'n ander moontlikheid. In hierdie geval is die probleem dat die benaming te wyd is. Dit sluit byvoorbeeld ook die Lutherse en Katolieke wetenskaplike in, wie se wetenskapsbeoefening ( $\mathrm{vgl}$. die tweede en derde visies onder 3.3) dualisties en akkommoderend en nie integraal en reformerend is nie.

\subsection{Ander voorstelle}

In die loop van die geskiedenis is verskillende ander name voorgestel om dié spesifieke Christelike tradisie, wat 'n wêreldtransformerende visie huldig, te beskryf.

- Tydens die sestiende-eeuse Reformasie is dit dikwels as Evangelies beskryf, omdat die Reformatore weer alle klem op die goddelike gesag van die evangelie gelê het (sola Scriptura - die Skrif alleen). Vandag dra die woord Evangelies (Evangelical) egter 'n ander, dikwels dualistiese, betekenis.

- Vroeg in die vorige eeu is gereformeerd(e) dikwels gebruik. (Vir die geskiedenis van die begrip reformasie, waarvan (ge)reformeerd afgelei is, vgl. Ladner, 1967 en Van der Walt, 1991, 2000a en 2002.) Baie Christelike organisasies het dit in hulle name opgeneem. Later het veral nie-kerklike, Christelike organisasies en onderwysinstellings egter begin besef dat die begrip ' $n$ te eng kerklike konnotasie het.

- Vir 'n tyd lank was die woord Calvinisties algemeen in gebruik. Die probleem daarmee was egter dat dit van die naam van 'n mens (Calvyn) afgelei is. Dit kon dus op mensverheerliking dui. Bowendien het Calvyn nie die laaste woord oor alles gespreek 
nie. (Calvyn het tewens self gesê dat wat hervorm is, voortdurend reformeer moet word, anders deformeer dit. Bowendien het hy tydgenote en navolgers gehad wat ook "Calvinisties" (Skrifgebonde) gedink het.

- Calvinisties is vanaf ongeveer 1960 geleidelik vervang met reformatories. Volgens Bartholomew (2000:3) was Calvin Seerveld die persoon wat eerste dié term gebruik het. Uit die volgende aanhaling is duidelik watter inhoud hy daaraan gegee het:

The term 'reformational' was coined by Seerveld in 1959 to catch several related meanings. It identifies, firstly, a life that seeks to be reformed by the reneval of our consciousness so that we can discern God's will for action on earth. Secondly, it identifies an approach that knows the genius of the Reformation, further developed by Groen van Prinsterer and Abraham Kuyper in the nineteenth century, as a distinct tradition out of which one can richly serve the Lord. Thirdly, it identifies a concern to communally keep reforming rather than get stuck in the past. In this sense Seerveld considers the philosophical work of Dooyeweerd and Vollenhoven as continued reformation of the neocalvinistic tradition (Bartholomew, 2000:3).

Met reformatories word dus duidelik nie na 'n statiese en eng kerklik-dogmatiese posisie verwys nie, maar na 'n dinamiese en omvattende Christelike lewensvisie, filosofie en wetenskapsbeoefening, wat op alle fasette van die lewe 'n impak wil hê.

- Die heel nuutste terme is transformasie/transformasioneel/ transformatief. Behalwe dat dit vandag 'n modewoord in die omgangstaal is het dié begrip ook die voordeel dat dit nie die misverstand kan wek wat aan die woord gereformeerd of selfs reformatories geheg kan word nie, naamlik dat dit 'n blote herhaling sou wees van wat vroeër bestaan het - repristinasie en dus niks nuuts na vore bring nie en dat reformasie dus 'n reeds voltooide, in die verlede afgehandelde taak sou wees.

Die belangrikste rede waarom ook Christene die woord deesdae gebruik, is omdat hulle meen dat reformasie impliseer dat die reeds bestaande verander word, terwyl transformasie die verkeerde verwerp en iets nuuts in die plek daarvan stel en gevolglik meer toekomsgerig is.

Durand (2002:17) motiveer sy keuse vir dié term byvoorbeeld soos volg: 
Die woord 'transformasie' dra 'n betekenis wat nie so direk uit 'reformasie' en 'hervorming' afgelei kan word nie. Laasgenoemde twee woorde wys, op die klank af, na die verlede. Hulle wys na dinge wat in die verlede verkeerd gegaan het en nou reggestel word. 'Transformasie', daarenteen, verwys óók in hierdie sin na die verlede, maar het nie net met die verlede te doen nie; dit sluit ook die toekoms oop. Dit gaan immers om transformasie. Die trans verwys na dit wat anderkant lê - die nuwe wat uit die ou vorm na vore sal kom.

Hoe gaan so 'n transformasieonele Christelike wetenskap te werk?

\section{Transformasionele wetenskapsbeoefening in die praktyk}

Op die vakgebied van die Filosofie was Klapwijk (vgl. 1987, 1991 en 1995 asook Vos, 1997) die eerste Reformatoriese denker wat 'n transformasionele filosofie bepleit het. Hoewel Klapwijk op die taak van 'n Christelike, transformatiewe filosofie toespits, geld heelwat van wat hy hier sê ook vir Christelike wetenskapsbeoefening in die algemeen.

Die vraag is wat iemand, wat vanuit 'n Christelike lewensvisie en filosofie dink, se houding moet wees teenoor sy eie of ander kulture en ook die wetenskap as belangrike onderdeel daarvan.

\subsection{Verskillende houdings}

Volgens Klapwijk kan daar gedurende die tweeduisendjarige geskiedenis van die Christendom in hoofsaak drie houdings onderskei word, naamlik isolasie, akkommodasie en transformasie. Op hierdie drie wyses het Christene deur die eeue standpunt ingeneem ten opsigte van die antieke Griekse en Romeinse kulture (preChristelike kulture en filosofieë wat die Bybel nog nie geken het nie) en teenoor die moderne sekulêre Westerse kulture en filosofieë (postChristelik van aard, omdat hulle die Christelike geloof geken, maar bewustelik verwerp het).

\subsubsection{Isolasie}

Hierdie hoofstroom het antiteties of afwysend teenoor die omringende kultuur en denkwêreld gestaan, omdat geglo is dat ' $n$ ware Christen alleen afgesonderd van die (sondige) wêreld kan bestaan. Hulle kon hulle beroep op Bybeltekste soos Kolossense 2:8 (OAV): "Pasop dat niemand julle as buit wegvoer deur die wysbegeerte en nietige misleiding nie, volgens die oorlewering van mense, volgens 
die eerste beginsels van die wêreld en nie volgens Christus nie"; "Vir God is die wysheid van die wêreld onsin" (1 Kor. 1:18-25); "'n Gelowige mag dus nie in dieselfde juk met 'n ongelowige trek of dieselfde belange hê nie" (2 Kor. 6:14-16).

\subsubsection{Akkommodasie}

Die teenoorgestelde van die antitetiese was die sintetiese denkrigting. (Hier pas die integrasiemodel.) Dit het dikwels tot so 'n mate gebeur dat die kommunikasie met die nie-Bybelse denke en wetenskap op aanpassing uitgeloop het - 'n verflouing en afwatering van die Christelike oortuigings.

Nie een van hierdie twee standpunte kan volgens Klapwijk egter werklik konsekwent onder Christene uitgeleef word nie. Die isolasiedenkers kon hulle wetenskap nie werklik van die omringende kultuur, geestelike klimaat en wetenskap, waarin hulle daagliks verkeer het, afsluit nie. Klapwijk is van mening dat sy voorgangers in die reformatoriese filosofie te sterk antiteties gedink het. En, indien die akkommodasiedenkers konsekwent was, sou hulle hul wetenskap nie meer werklik Christelik kon noem nie.

\subsubsection{Transformasie}

In albei standpunte is daar volgens Klapwijk nogtans 'n waarheidselement, want die korrekte Christelike lewenshouding is antiteties en sinteties tegelyk. Dit is antiteties, omdat 'n Christen op grond van God se openbaring nie die wêreldse wysheid kan aanvaar nie. Dit is terselfdertyd ook sinteties, omdat 'n Christen 'n kind van sy tyd is en hom/haarself nooit volledig kan losmaak van die gees van sy eie tyd wat die heersende vrae en antwoorde bepaal het.

2 Korintiërs 10:5 vat die antitetiese en sintetiese houding soos volg saam: aan die een kant vernietig ons met die kragtige wapens wat God tot ons beskikking stel, die ongelowige redenasies en hooghartige aanvalle teen God. Aan die ander kant word elke (ongelowige) gedagte gevange geneem om dit aan Christus gehoorsaam te maak.

\subsection{Twee tipes transformasie}

Transformasie is ' $n$ saak of aktiwiteit en mag nie tot norm verhef word nie. Dit moet normatief beoordeel word. Dus is nie elke vorm van transformasie vir 'n Christen aanvaarbaar nie. In die lig van die Skrif moet, volgens Klapwijk, onderskei word tussen normatiewe en anti-normatiewe transformasie. 


\subsubsection{Normatiewe transformasie}

Die belangrikste vraag is hier hoe die Christelike geloof, lewensvisie en filosofie die kultuur (insluitende die wetenskap as onderdeel daarvan) volgens die maatstawwe van God se Woord kan verander, sodat hulle weer God se doel vir die skepping kan bevorder.

Klapwijk verduidelik dit soos volg: Moses gee (Eks. 12:35, 36) voor hulle uittog uit Egipte aan die Israeliete opdrag om van die Egiptenare silwer en goue voorwerpe te eis. Só moet 'n Christen ook met die (ou en moderne) heidense kultuur en wetenskap maak - hy moet daarop beslag lê. Dit mag egter nie op die wyse geannekseer word as wat die Israeliete gedoen het nie. Hulle maak later (vgl. Eks. 32:1-4) van die goue voorwerpe 'n goue kalf om dit as god te aanbid. Dit was 'n voortsetting van die heidense Egiptenare se diereverering. Dit was dus gewoon 'n aanpassing by (akkommodasie aan of sintese met) die heidense gebruike. Eers later word die geroofde Egiptiese goud reg aangewend toe dit omgesmelt is vir die bou van die tabernakel, 'n woonplek vir die ware God (vgl. Eks. 35:4-9).

Normatiewe, korrekte transformasie vereis volgens Klapwijk dus 'n kritiese verwerking vanuit die Christelike geloof van die nieChristelike kultureel-wetenskaplike produkte. Dit beteken "omsmelting" of "suiwering" in die "vuur" van God se Woord. Kritiese verwerking beteken dat die waardevolle insigte in die nie-Christelike kultuur en wetenskap losgemaak word uit hulle religieuse (ideologiese) voedingsbodem, of uit hulle lewensbeskoulike konteks, sodat hulle binne 'n Christelike lewensbeskouing en wetenskap geïntegreer kan word en werklik diensbaar kan wees in die koninkryk van God.

\subsubsection{Anti-normatiewe transformasie}

Die gevaar verbonde aan alle pogings tot transformasie is dat omgekeerde transformasie kan plaasvind. In plaas daarvan dat die Christelike geloof, lewensvisie en filosofie die verskillende fasette van die kultuur, insluitend die wetenskap, verander, vind die teenoorgestelde plaas. Christelike oortuigings word só omgebuig dat hulle vir gelowiges byna onherkenbaar word. Verlossing word byvoorbeeld selfverlossing; die waarheid word tot subjektiewe gevoelens verdun; gesag word as mag geïnterpreteer; liefde word selfbevrediging, en nog baie meer. In sulke gevalle vind in plaas van die kerstening van die kultuur die omgekeerde, naamlik die ontkerstening of sekularisasie van die Christelike geloof en wetenskap plaas. 
Inverse, anti-normatiewe transformasie kom nie net by nie-Christene voor nie. Dié twee vorme van transformasie kan selfs by dieselfde Christendenker aangetref word. Dit gebeur wanneer iemand in sommige opsigte daarin slaag om die boodskap en die norme van God se Woord helder en duidelik te maak vir sy kultuur en wetenskapsbeoefening, maar in ander opsigte nog steeds die prooi is van onbybelse gedagtes.

Openheid na die wêreld hou altyd die gevaar in van openheid vir die wêreldse (sondige). Aan die een kant moet Christene vanuit hulle Christelike lewensvisie, filosofie en ander wetenskappe op die aktuele probleme van hulle tyd ingaan en aantoon wat die implikasies van hulle Christelike geloof vir die probleme is, sodat daar reformasie kan plaasvind. Aan die ander kant kan betrokkenheid by die eietydse vraagstukke ook tot deformasie lei wanneer die suigkrag van die omringende kultuur en wetenskap te sterk word.

\subsubsection{Drie kenmerke van transformasie}

Transformasie het drie kenmerke, naamlik dat dit dinamies, kontekstueel en gedifferensieerd is.

Indien transformasie vanuit 'n normatiewe, Christelike perspektief die krities-selektiewe verwerking van die produkte van verskillende kulture is, kan dit nie staties wees nie, maar is dit dinamies. Dit is byvoorbeeld nie moontlik om 'n permanente Christelike filosofie ('n philosophia perennis christiana) daar te stel wat vir altyd vir alle mense, tye en plekke sou geld nie.

Omdat transformasie nie isolasie voorstaan nie, kan dit tweedens ook kontekstueel wees. Dit is betrokke by die mense binne die konteks waarin hulle lewe, met al hulle vrae, onsekerhede, frustrasies en aspirasies. Daarom kan so 'n soort transformasie werklik relevant wees.

Omdat Christelike filosofie en wetenskap op die kultuur van 'n bepaalde tyd, plek en mense reageer, kan dit in die derde plek nie inhoudelik presies dieselfde wees in Europa, Afrika, Asië of SuidAmerika nie. 'n Christelike filosofiese respons op die Europese kultuur kan nie eenvoudig na Afrika "uitgevoer" word nie, maar sal kontekstueel gedifferensieerd moet wees. 


\section{Slot: Integrasie of transformasie?}

In ooreenstemming met sy titel het hierdie artikel aan die begin die vraag gestel of die integrasie- of die transformasiemodel die ideaal vir Christelike wetenskapsbeoefening moet wees. Na grondinge oorweging is integrasie as ideaal nie geskik bevind nie. Daarom is die transformasionele model as antwoord op die vraag gegee. Hoewel die model nog deegliker bekyk sal moet word, hou dit belofte in. Voorlopig lyk dit na 'n stappie vooruit op die moeilike maar steeds boeiende weg van 'n werklike scientia transformanda.

\section{Geraadpleegde bronne}

BARTHOLOMEW, C., ed. 2000. In the fields of the Lord: a Calvin Seerveld reader. Toronto: Tuppence.

BEST, H.A. 1993. Music through the eyes of faith. New York: Harper-Collins.

BOTHA, M.E. 2004. Hoe staan dit met Christelike onderwys in Noord-Amerika (VSA en Kanada)? Woord en Daad, 44(390):12-16, Somer.

BOUMA-PREDIGER, S. 1990. The task of integration: a modest proposal. Journal of Psychology and Theology, 18(1):21-31.

BYL, J. 2001. God and cosmos: a Christian view of time, space and the universe. Edinburgh: The Banner of Truth Trust.

CHAPLIN, J. et al. 1986. Introduction to a Christian worldview. London: Open Christian College.

CLOUSER, R. 1991. The myth of neutrality: an essay on the hidden role of religious beliefs in theories. Norte Dame: University of Nortre Dame Press.

COLETTO, R. 2002. Models of scholarship in the reformed tradition. Potchefstroom: PU for CHE. (M.A. thesis.)

COLSON, C. \& PEARCEY, N. 1999. How now shall we live? Wheaton: Tyndale House.

DEMOL, K.A. 1999. Sound stewardship, how shall Christians think about music? Sioux Center, lowa: Dordt College Press.

DURAND, J. 2002. Ontluisterde wêreld: die Afrikaner en sy kerk in 'n veranderde wêreld. Wellington: Lux Verbi.

ERASMUS, T. \& KRUGER, J. 2004. Wie vs. Hoe: vrae oor geloof en wetenskap. Die Kerkblad, 107(3169):30-32, November.

FOWLER, S. 2001. Contours of a reformational scholarship. (In Kok, J., ed. Marginal resistance: essays dedicated to John C. Vander Stelt. Sioux Center: Dordt College Press. p. 129-152.)

FRASER, D.A. \& CAMPOLO, T. 1992. Sosiology through the eyes of faith. New York: Harper-Collins.

GOUDZWAARD, B. 1984. The idols of our time. Downers Grove: InterVarsity.

HEIE, H. \& WOLFE, D., eds. 1987. The reality of Christian learning: strategies for faith-learning integration. Grand Rapids: Eerdmans.

HEYNS, M.F. 1999. Op soek na die werklikheid. Potchefstroom: PU vir $\mathrm{CHO}$. (Diktaat nr. D92/99.)

KRUGER, J.P. 2003. Die verhouding tussen geloof en wetenskap in die filosofie van C.A. van Peursen. Potchefstroom: PU vir CHO. (M.A.-verhandeling.)

KLAPWIJK, J. 1987. Reformational philosophy on the boundary between the past and the future. Philosophia Reformata, 52(2):101-134. 
KLAPWIJK, J. 1991. Epilogue: the idea of transformational philosophy. (In Klapwijk, J., Griffioen, S., Groenewoud, G., eds. Bringing into captivity every thought: capita selecta in the history of Christian evaluations of nonChristian philosophy. Lanham: University Press of America. p. 241-266.)

KLAPWIJK, J. 1995. Transformationele filosofie: cultuurpolitieke ideeën en de kracht van een inspiratie. Kampen: Kok Agora.

KOK, J. 2004. Learning to teach from within a Christian perspective. (In Kok, J., ed. Celebrating the vision: the Reformed perspective of Dordt College. Sioux Center: Dordt College Press. p. 55-68.)

LADNER, G.B. 1967. The idea of reform: its impact on Christian thought and action in the age of the fathers. New York: Harper \& Row.

MARSHALL, P. \& GILBERT, L. 1998. Heaven is not our home: learning to live in God's creation. Nashville: Word Publishing.

MARSHALL, P. et al. 1989. Stained glass: worldviews and social change. Lanham: University Press of America.

MYERS, D.G. \& JEEVES, M.A. 1987. Psychology through the eyes of faith. New York: Harper-Collins.

NAUGLE, D.K. 2002. Worldview: the history of a concept. Grand Rapids: Eerdmans.

PEARCEY, N. 2004. Total truth: liberating Christianity from its cultural captivity. Wheaton: Crossway Books.

SINNEMA, D. 2001. Beyond integration to holistic Christian scholarship. (In Kok, J., ed. Marginal resistance: essays dedicated to John C. Vander Stelt. Sioux Center: Dordt College Press. p. 187-208.)

SIRE, J.W. 1976. The universe next door, a guide to worldviews. Leicester: InterVarsity.

SIRE, J.W. 1990. Discipleship of the mind: learning to love God in the ways we think. Downers Grove: InterVarsity.

SPYKMAN, G.J. 1992. Reformational theology: a new paradigm for doing dogmatics. Grand Rapids: Eerdmans.

VAN BELLE, H. 2005. Structure and direction: the presence of God in the therapeutic relation. Lesing gelewer op 11/05/2005 by die Potchefstroomkampus van die Noordwes-Universiteit.

VAN BRUMMELEN, H. 2001. Persuing faith-based and faith-affirming learning. (In Kok, J., ed. Marginal resistance. Sioux Center: Dordt College Press. p. 209-222.)

VAN DER WALT, B.J. 1976. Die probleem van die verhouding tussen geloof en wete in die vroeg-Christelike en Middeleeuse denke. Tydskrif vir Christelike Wetenskap, 12:97-117.

VAN DER WALT, B.J. 1986. Wete en geloof; enkele flitse uit 'n duisendjarige worsteling met die probleem. (In Van der Walt, B.J. Van Athene na Genève: 'n kort oorsig oor die geskiedenis van die Wysbegeerte vanaf die Grieke tot die Reformasie. Potchefstroom: Pro Rege. p. 156-164.)

VAN DER WALT, B.J. 1991. Reformasie op die viersprong: pasmarkeerders, loodvoetiges, brandstigters of ligdraes? (In Van der Walt, B.J. Die idee van reformasie: gister en vandag. Potchefstroom: Instituut vir Reformatoriese Studie. p. 2-33.)

VAN DER WALT, B.J. 2000a. Enkele historiese bakens in die ontwikkeling van die idee van reformasie. (In Van der Walt, B.J. Visie op die werklikheid. Potchefstroom: Instituut vir Reformatoriese Studie. p. 144-150.) 
VAN DER WALT, B.J. 2000b. Visie op die werklikheid: die bevrydende krag van 'n Christelike lewensbeskouing en filosofie. Potchefstroom: Instituut vir Reformatoriese Studie.

VAN DER WALT, B.J. 2000c. The liberating message: a Christian worldview for Africa. Potchefstroom: Institute for Reformational Studies.

VAN DER WALT, B.J. 2001. Geloof as "versiersuiker" of "gaatjievuller": twee karikature van Christelike wetenskapsbeoefening. Woord en Daad, 41(377):1-3, Lente.

VAN DER WALT, B.J. 2002. The idea of reformation in the history of Christianity - a few landmarks. (In Van der Walt, B.J. The liberating message. Potchefstroom: The Institute for Contemporary Christianity in Africa. p. 320-325.)

VAN DER WALT, B.J. 2004. Die verhouding tussen geloof en wetenskap. Die Kerkblad, 107(3169):17-19, November.

VAN DER WALT, B.J. 2005. Transformed by the renewing of your mind: shaping a Biblical worldview and Christian perspective on scholarship. Potchefstroom: The Institute for Contemporary Christianity in Africa.

VOS, P. 1997. Christelijk geloof en transcendentaalfilosofie: over de relatie en die mogelijkheid tot communicatie. (In Van den Brink, G., Geertsema, H.G., Hoogland, J., reds. Filosofie en theologie: een gesprek tussen christen-filosofen en theologen. Amsterdam: Buijten \& Schipperheijn. p. 930.)

WALSH, B.J. \& MIDDLETON, J.R. 1984. The transforming vision: shaping a Christian worldview. Downers Grove: InterVarsity.

WOLTERS, A.M. 1985. Creation regained: Biblical basics for a reformational worldview. Grand Rapids: Eerdmans.

WOLTERS, A.M. 1990. Christianity and the classics: a typology of attitudes. (In Helleman, W.E., ed. Christianity and the classics: the acceptance of a heritage. Lanham: University Press of America. p. 189-203.)

WRIGHT, R.T. 1989. Biology through the eyes of faith. New York: HarperCollins.

ZYLSTRA, C. 1997. Faith-based learning: the conjunction in Christian scholarship. Pro Rege, 26:1-5, September.

\section{Kernbegrippe:}

Christelike wetenskapsbeoefening

geloof en wetenskap

integrasie van geloof en wetenskap

transformasie/transformasionele wetenskapsbeoefening

\section{Key concepts:}

Christian scholarship

faith/belief and science

integration of faith and science

transformation/transformational scholarship 
